\title{
Francisella tularensis Confronts the Complement System
}

\author{
Susan R. Brock and Michael J. Parmely* \\ Department of Microbiology, Molecular Genetics and Immunology, University of Kansas Medical Center, Kansas City, KS, \\ United States
}

Francisella tularensis has developed a number of effective evasion strategies to counteract host immune defenses, not the least of which is its ability to interact with the complement system to its own advantage. Following exposure of the bacterium to fresh human serum, complement is activated and C3b and iC3b can be found covalently attached to the bacterial surface. However, the lipopolysaccharide and capsule of the F. tularensis cell wall prevent complement-mediated lysis and endow the bacterium with serum resistance. Opsonization of $F$. tularensis with C3 greatly increases its uptake by human neutrophils, dendritic cells and macrophages. Uptake occurs by an unusual looping morphology in human macrophages. Complement receptor 3 is thought to play an important role in opsonophagocytosis by human macrophages, and signaling through this receptor can antagonize Toll-like receptor 2-initiated macrophage activation. Complement C3 also determines the survival of infected human macrophages and perhaps other cell types. C3-opsonization of $F$. tularensis subsp. tularensis strain $\mathrm{SCHU}$ S4 results in greatly increased death of infected human macrophages, which requires more than complement receptor engagement and is independent of the intracellular replication by the pathogen. Given its entry into the cytosol of host cells, F. tularensis has the potential for a number of other complement-mediated interactions. Studies on the uptake C3-opsonized adenovirus have suggested the existence of a C3 sensing system that initiates cellular responses to cytosolic C3b present on invading microbes. Here we propose that C3 peptides enter the cytosol of human macrophages following phagosome escape of $F$. tularensis and are recognized as intruding molecular patterns that signal host cell death. With the discovery of new roles for intracellular $\mathrm{C} 3$, a better understanding of tularemia pathogenesis is likely to emerge.

University of lowa, United States

*Correspondence:

Michael J. Parmely mparmely@kumc.edu

Received: 31 October 2017 Accepted: 08 December 2017 Published: 19 December 2017

Citation: Brock SR and Parmely MJ (2017) Francisella tularensis Confronts the Complement System.

Francisella tularensis is the bacterial pathogen responsible for the infectious disease tularemia. While tularemia is relatively rare, infection via the respiratory route can be particularly lifethreating when not treated with appropriate antibiotics in a timely fashion (Stuart and Pullen, 1945; McCrumb, 1961; Dennis et al., 2001; Feldman et al., 2001). There are two subspecies of F. tularensis that account for the majority of infections in immunocompetent human beings. F. tularensis subsp. tularensis (type A) is considered the more virulent and will be the primary focus of this article. F. tularensis subsp. holarctica (type B) is also pathogenic in humans, but is less often associated with severe morbidity or mortality. Francisella novicida causes a tularemia-like disease in mice, but rarely infects human beings where disease is restricted to the immunocompromised (Kingry and Petersen, 2014). Following exposure to type A and type B F. tularensis by the pulmonary route, 
macrophages are among the first cells infected (Hall et al., 2008; Roberts et al., 2014; Steiner et al., 2017) and serve as an early and continuing replicative niche for the pathogen. Many receptors on the macrophage surface have been implicated in the uptake of F. tularensis (Clemens et al., 2005; Balagopal et al., 2006; Pierini, 2006; Schulert and Allen, 2006; Barel et al., 2008; Geier and Celli, 2011; Schwartz et al., 2012; Dai et al., 2013), but complement receptors, especially CR3, have consistently been found to be the primary mediators of enhanced uptake of serumopsonized F. tularensis by human macrophages (Clemens et al., 2005; Schwartz et al., 2012; Dai et al., 2013). Once inside the cell, $F$. tularensis escapes the macrophage phagosome at a pace that varies with host species and replicates in the cytosol to high numbers (Golovliov et al., 2003; Clemens et al., 2004; Chong et al., 2008).

Macrophage death is a common outcome following in vivo infection with $F$. tularensis and partially explains the appearance of necrotic foci in the livers, lungs, spleens and lymph nodes in several mammalian species (Parmely et al., 2009). The mechanisms and significance of macrophage death depend on the (sub)species of Francisella studied (Mariathasan et al., 2005; Henry et al., 2007; Wickstrum et al., 2009). For example, F. novicida is a highly proinflammatory pathogen, which induces rapid cell death in mouse macrophages that limits the ability of the bacteria to replicate in the host (Mariathasan et al., 2005; Henry et al., 2007). When describing the lifecycle of type A and type B F. tularensis, it is not uncommon to attribute macrophage death to an uncharacterized signal associated with the extensive cytosolic replication of the pathogen. For example, Lai et al. reported on the effects of antibiotic treatment of J774.A1 macrophage-like cells infected with the F. tularensis Live Vaccine Strain (LVS) (Lai et al., 2001). Treating cultures with ciprofloxacin within the first $12 \mathrm{~h}$ of infection prevented both the replication of the bacteria and host cell death measured $24 \mathrm{~h}$ post-infection (PI). If ciprofloxacin treatment was delayed until $15 \mathrm{~h}$ PI, host cell death at $24 \mathrm{~h}$ PI was similar in magnitude to that of untreated, infected control cells. The authors concluded that intracellular bacterial replication was required for the induction of macrophage death. Recent studies performed in our laboratory with type A F. tularensis (Brock and Parmely, 2017) have questioned this interpretation. Intracellular replication of the SCHU S4 strain did not appear to be required for the induction of death in primary human macrophages.

During the course of these studies, we found that complement C3 played an important role in determining the survival of infected macrophages. Accordingly, in this article we review what is known about the interactions between $F$. tularensis and the complement system, discuss recent findings about the functions of intracellular complement, and propose new ways of thinking about the complement system in tularemia. Our primary focus will be on F. tularensis subsp. tularensis, although our use of

Abbreviations: $\mathrm{BMM}$, bone marrow-derived macrophage; $\mathrm{CR}$, complement receptor; FB, factor $\mathrm{B}$; FD, factor D; FI, factor I; HS, human serum; MDM, monocyte-derived macrophage; MOI, multiplicities of infection; PI, postinfection. the designation $F$. tularensis reflects an effort to include relevant studies performed with subsp. holartica strains. We acknowledge this comes with the risk that future studies may prove some conclusions to be too inclusive.

\section{EXTRACELLULAR COMPLEMENT ACTIVATION AND REGULATION}

For detailed descriptions of complement activation, the reader is referred to several excellent reviews (Dunkelberger and Song, 2010; Ricklin et al., 2010; Noris and Remuzzi, 2013). There are three pathways of complement activation (Figure 1), all of which result in the proteolytic cleavage of complement component C3, an abundant serum protein. The classical and lectin pathways both generate a C3 convertase composed of the peptides $\mathrm{C} 4 \mathrm{~b}$ and $\mathrm{C} 2 \mathrm{a}$. Through the classical pathway, IgM and IgG antibodies, when bound to their respective antigens,

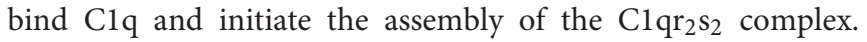
This complex cleaves C4 and C2 to produce a C3 convertase, designated $\mathrm{C} 4 \mathrm{bC} 2 \mathrm{a}$. In the lectin pathway, the binding of certain carbohydrate patterns on microorganisms by either serum mannose-binding lectin (MBL) or ficolin proteins recruits and activates mannose-binding lectin-associated serine proteases (MASPs), which cleave C4 and C2 to generate the same C3 convertase. The alternative pathway is constitutively active with a low level "tick-over" of C3 in which an internal thioester bond is spontaneously hydrolyzed yielding $\mathrm{C} 3\left(\mathrm{H}_{2} \mathrm{O}\right)$. Hydrolyzed $\mathrm{C} 3$ has a conformation similar to C3b (Chen et al., 2016) and can bind complement factor B (FB). Constitutively active factor $\mathrm{D}(\mathrm{FD})$ then cleaves $\mathrm{FB}$, yielding an alternative pathway $\mathrm{C} 3$ convertase designated $\mathrm{C} 3\left(\mathrm{H}_{2} \mathrm{O}\right) \mathrm{Bb}$. Like the $\mathrm{C} 4 \mathrm{~b} 2 \mathrm{a}$ convertase, the alternative pathway convertase can cleave $\mathrm{C} 3$ to produce a bioactive short $\mathrm{C} 3 \mathrm{a}$ peptide and a lengthier $\mathrm{C} 3 \mathrm{~b}$ peptide (Figure 2). C3a can serve as an anaphylatoxin. One of the primary functions of $\mathrm{C} 3 \mathrm{~b}$ is as a potent opsonin, which is attributed to its exposed thioester bond. Unless C3 has been spontaneously hydrolyzed by water, the $\mathrm{C} 3 \mathrm{~b}$ thioester can react with amine or hydroxyl groups. Formation of amide or ester linkages assures covalent attachment of $\mathrm{C} 3 \mathrm{~b}$ to nearby target surfaces, which makes them stable ligands for complement receptor-mediated uptake.

The alternative pathway also serves to amplify complement activation initiated by any of the three pathways by utilizing $\mathrm{C} 3 \mathrm{~b}$ as a focus for the formation of additional $\mathrm{C} 3$ convertases. Thus, $\mathrm{C} 3 \mathrm{~b}$ bound to a surface can form a complex with $\mathrm{FB}$, which when cleaved by $\mathrm{FD}$, becomes the new alternative pathway $\mathrm{C} 3$ convertase $\mathrm{C} 3 \mathrm{bBb}$. This amplification process results in increased localized activation of complement in proximity to susceptible microbial surfaces.

The binding of $\mathrm{C} 3 \mathrm{~b}$ to $\mathrm{C} 3$ convertases changes their specificity to C5-cleaving enzymes. Proteolysis of C5 produces the peptides C5a (another anaphylatoxin and potent chemotactic factor) and $\mathrm{C} 5 \mathrm{~b}$, which initiates formation of the membrane attack complex. C5b binds C6, which then complexes with C7 and inserts into lipid membranes. The C5b67 complex then interacts with 


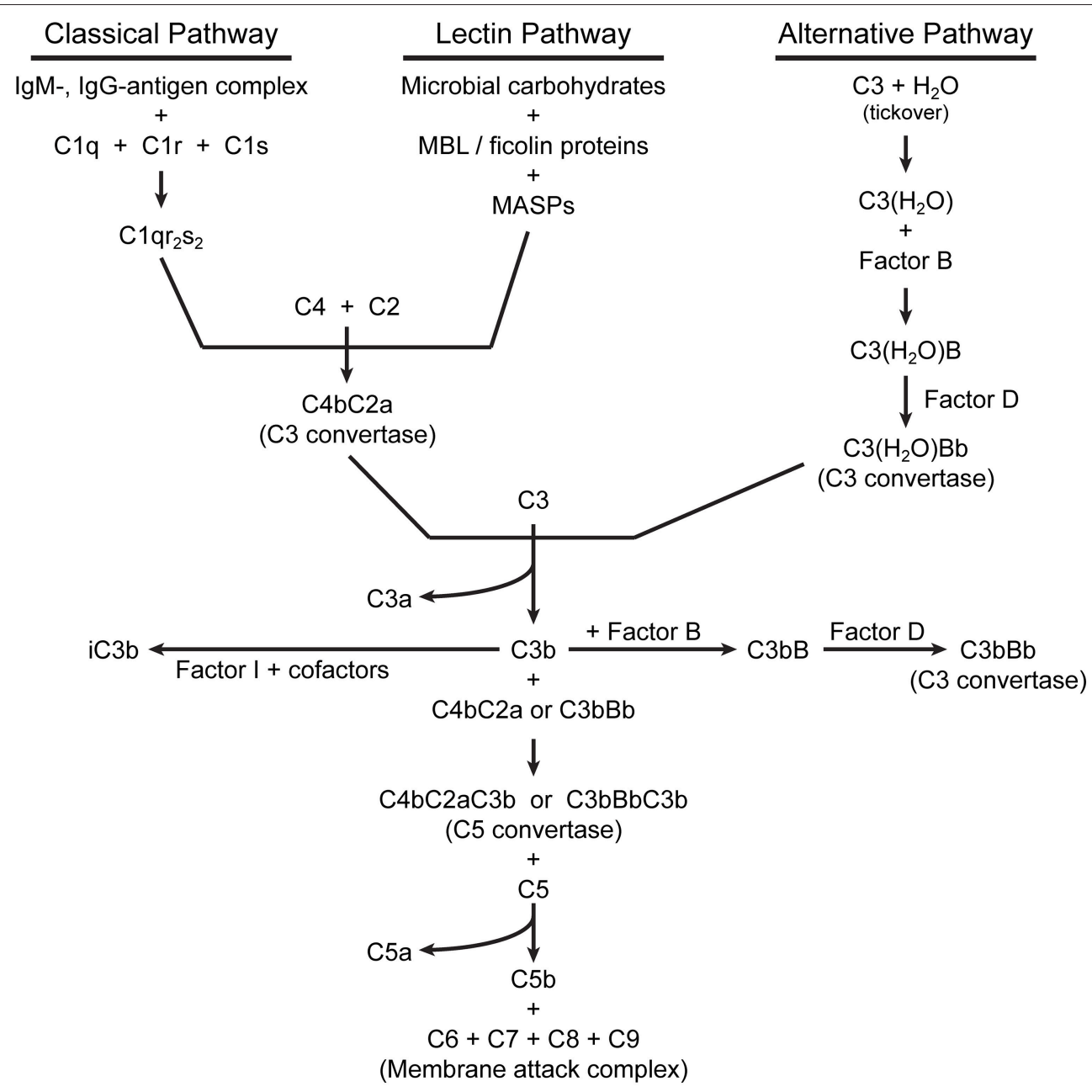

FIGURE 1 | Pathways of extracellular complement activation.

C8, followed by recruitment of multiple copies of $\mathrm{C} 9$, which polymerize to form a membrane pore, followed by rapid cell lysis.

Complement activation is tightly regulated by a variety of serum and membrane-bound proteins that control the three complement pathways (reviewed in Zipfel and Skerka, 2009; Noris and Remuzzi, 2013). The primary outcome is to limit host tissue damage that would result from unabated complement activation. Only two of these regulatory components will be mentioned here. Factor I (FI) is a serum protein that, along with certain cofactors, cleaves the alpha chain of $\mathrm{C} 3 \mathrm{~b}$ yielding inactivated $\mathrm{C} 3 \mathrm{~b}$ (iC3b) (Figure 2). The formation of iC3b terminates amplification of the complement cascade by preventing formation of additional C3 convertases and also halts C5 cleavage, which diminishes assembly of the membrane attack complex. However, iC3b retains its opsonic activity, albeit with different complement receptor specificity than that of C3b. Factor $\mathrm{H}(\mathrm{FH})$ serves as a co-factor for FI and also competes with FB binding to $\mathrm{C} 3 \mathrm{~b}$, preventing formation of the alternative pathway C3 convertase.

\section{CELL SURFACE RECEPTORS FOR C3}

In addition to fluid phase complement factors, there are many membrane bound complement receptors that are important for complement regulation and complement-mediated clearance, phagocytosis and cellular signaling. Here we will discuss membrane bound complement receptors that have been shown to have important implications for F. tularensis virulence and host defense. For a comprehensive review of complement receptors, the reader is referred to two important reviews (Leslie, 2001; Zipfel and Skerka, 2009). Complement receptor 1 (CR1or CD35) is expressed on leukocytes and erythrocytes and binds C3b (Table 1). In addition to its role in complement-mediated opsonophagocytosis, CR1 serves as a membrane-bound cofactor for $\mathrm{FI}$, leading to conversion of $\mathrm{C} 3 \mathrm{~b}$ to $\mathrm{iC} 3 \mathrm{~b}$. CR3 is a heterodimer of the membrane proteins CD11b and CD18 and is expressed on neutrophils, macrophages, follicular dendritic cells, eosinophils, basophils, NK cells and platelets. CR3 shows high affinity for iC3b, which facilitates phagocytosis of iC3b-bearing particles. While we will focus primarily on the opsonic activities of these 


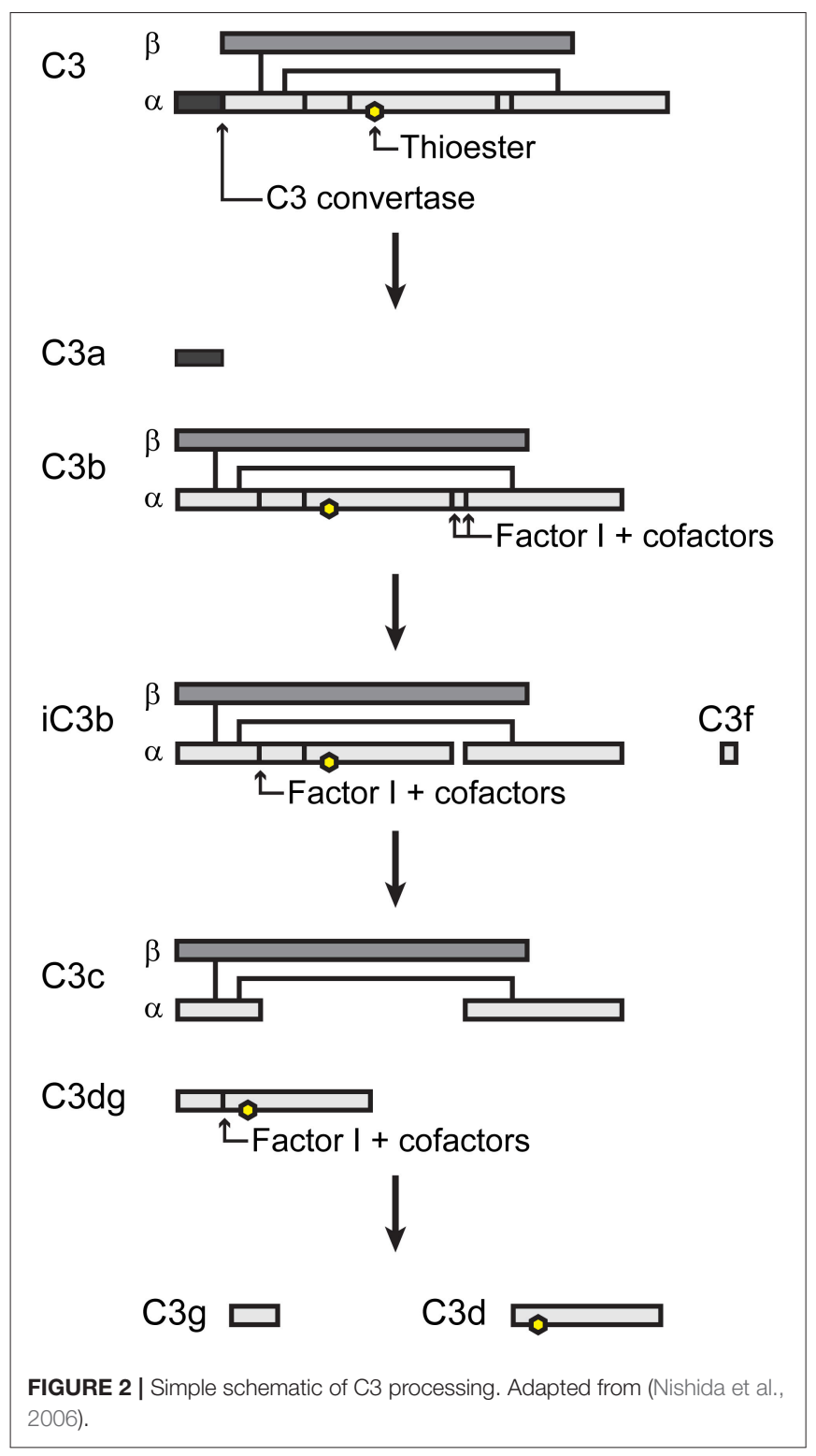

receptors, CR3 also plays a role in leukocyte trafficking to sites of infection and regulating cellular responses initiated by certain Toll-like receptors. CR4 is comprised of heterodimers of CD11c and CD18 and is expressed on monocytes and macrophages. CR4 also binds iC3b with high affinity.

Apart from the involvement of complement receptors in the uptake of $F$. tularensis by phagocytic cells, little research has investigated the role of other cell surface complement receptors and regulators. For example, tissue macrophages also express the complement receptor CRIg, which binds the beta chain of $\mathrm{C} 3$, allowing the receptor to phagocytize both $\mathrm{C} 3 \mathrm{~b}$ - and iC3bopsonized particles. CRIg is important for the clearance of pathogens (Helmy et al., 2006; van Lookeren Campagne et al., 2007), but its role during F. tularensis infection has not been investigated. Mature B cells express CR2 (or CD21), which binds $\mathrm{iC} 3 \mathrm{~b}, \mathrm{C} 3 \mathrm{dg}$ and $\mathrm{C} 3 \mathrm{~d}$ peptides derived from FI-mediated cleavage of $\mathrm{iC} 3 \mathrm{~b}$. One report suggests that subsets of mouse B cells employ CR2 along with the $\mathrm{B}$ cell receptor for uptake of $F$. tularensis (Plzakova et al., 2015). CD46, CD55 and CD59 are expressed by most host cell types, regulate complement activation and protect host tissues from complement-mediated damage by aiding in the inactivation of $\mathrm{C} 3$, disrupting the $\mathrm{C} 3$ convertases or preventing the formation of the membrane attack complex, respectively. Whether or not these complement regulators play a role in F. tularensis virulence or host defense is unknown.

\section{INTRACELLULAR ACTIONS OF COMPLEMENT}

Based on phylogenetic studies and the presence of C3like proteins in porifera (sponges), Elvington et al. have suggested that complement proteins served first to protect the intracellular space before evolving into a system for defending against pathogens at the cell membrane or in intercellular or intravascular domains of higher organisms (Elvington et al., 2016). Only recently have we begun to appreciate the extent to which complement mediates important intracellular functions (reviewed in Arbore et al., 2017; Liszewski et al., 2017).

Many cell types produce C3 (Lubbers et al., 2017) and maintain intracellular stores of the protein (Liszewski et al., 2013). Elvington et al. recently showed that intracellular C3 derives from a $\mathrm{C} 3\left(\mathrm{H}_{2} \mathrm{O}\right)$ recycling pathway in which hydrolyzed, but not native, $\mathrm{C} 3$ is taken up from the extracellular environment (Elvington et al., 2017). After being loaded with $\mathrm{C} 3\left(\mathrm{H}_{2} \mathrm{O}\right)$, Farage B lymphoma cells released $\sim 80 \%$ of the $\mathrm{C} 3\left(\mathrm{H}_{2} \mathrm{O}\right)$ back into the culture medium, suggesting that the cells processed the remainder as a source of bioactive C3 peptides (Liszewski et al., 2013; Elvington et al., 2017). Complement receptors CR1, CR2, CR3, and CD46 did not appear to be involved in the uptake of $\mathrm{C} 3\left(\mathrm{H}_{2} \mathrm{O}\right)$ in this recycling pathway (Elvington et al., 2017).

Liszewski and colleagues have extensively documented mechanisms of C3 activation within cells (Liszewski et al., 2013). For example, cathepsin L can cleave C3 to form C3a and C3b within the lysosomes of human $\mathrm{T}$ cells. The resulting $\mathrm{C} 3 \mathrm{a}$ mediates the tonic intracellular activation of its complement receptor $\mathrm{C} 3 \mathrm{aR}$ on the lysosome membrane, leading to baseline mTOR activation necessary for $\mathrm{T}$ cell homeostasis. Inhibition of cathepsin L or siRNA inhibition of C3aR expression led to $\mathrm{T}$ cell apoptosis. Activation of $\mathrm{T}$ cells through their antigen receptors resulted in the transport of vesicles containing $\mathrm{C} 3 \mathrm{aR}$, $\mathrm{C} 3$ and cathepsin $\mathrm{L}$ to the cell surface. In an autocrine fashion, cleavage of $\mathrm{C} 3$ at the cell surface and binding of $\mathrm{C} 3 \mathrm{a}$ and $\mathrm{C} 3 \mathrm{~b}$ to their respective receptors, $\mathrm{C} 3 \mathrm{aR}$ and $\mathrm{CD} 46$, polarized the $\mathrm{T}$ cell to a Th1 phenotype (Liszewski et al., 2013; Kolev et al., 2015).

Intracellular activation of $\mathrm{C} 3$ is not limited to $\mathrm{T}$ cells. It has also been demonstrated in a variety of primary human cell types including monocytes, neutrophils, and B cells, as well as cultured human fibroblasts, ME-180 epithelial cells and umbilical vein endothelial cells (Liszewski et al., 2013). The proteases responsible for intracellular $\mathrm{C} 3$ cleavage vary among cell types. 
TABLE 1 | Human complement receptors with known involvement in the uptake of serum-opsonized F. tularensis.

\begin{tabular}{|c|c|c|c|c|}
\hline Complement receptor & Preferred ligand* & Cell expression* & Function in F. tularensis infection & References \\
\hline CR1 (CD35) & C3b, C4b & $\begin{array}{l}\text { Leukocytes (including neutrophils and } \\
\text { macrophages) and erythrocytes }\end{array}$ & $\begin{array}{l}\text { Uptake of serum-opsonized } F \text {. tularensis } \\
\text { by human neutrophils }\end{array}$ & Schwartz et al., 2012 \\
\hline CR3 (CD11b, CD18) & iC3b & $\begin{array}{l}\text { Neutrophils, macrophages, follicular } \\
\text { dendritic cells, eosinophils, basophils, NK } \\
\text { cells and platelets }\end{array}$ & $\begin{array}{l}\text { Uptake of serum-opsonized } F \text {. tularensis } \\
\text { by human neutrophils, macrophages and } \\
\text { dendritic cells } \\
\text { Crosstalk with TLR2-inhibition of } \\
\text { TLR2-mediated inflammatory signaling }\end{array}$ & $\begin{array}{l}\text { Clemens et al., 2005; Ben } \\
\text { Nasr et al., 2006; Schwartz } \\
\text { et al., 2012; Dai et al., } 2013\end{array}$ \\
\hline CR4 (CD11c, CD18) & iC3b & Monocytes and macrophages & $\begin{array}{l}\text { Uptake of serum-opsonized F. tularensis } \\
\text { by macrophages and dendritic cells }\end{array}$ & $\begin{array}{l}\text { Ben Nasr et al., 2006; } \\
\text { Schwartz et al., } 2012\end{array}$ \\
\hline
\end{tabular}

${ }^{*}$ Receptor ligand specificity and cell expression obtained from Leslie (2001) and Zipfel and Skerka (2009).

While cathepsin $\mathrm{L}$ mediates activation of $\mathrm{C} 3$ in $\mathrm{T}$ cells and monocytes, it is not responsible for the $\mathrm{C} 3$ activation observed in lung epithelial cells (Liszewski et al., 2013). Both cathepsin $\mathrm{L}$ and cathepsin $\mathrm{B}$ contribute to $\mathrm{C} 3$ cleavage within human intestinal epithelial cells (Satyam et al., 2017). Factor H and FI can be taken up by cells and mediate intracellular cleavage of $\mathrm{C} 3\left(\mathrm{H}_{2} \mathrm{O}\right)$ (Elvington et al., 2017). Factor $\mathrm{H}$ has also been shown to interact with cathepsin $\mathrm{L}$ to increase cleavage of endogenous $\mathrm{C} 3$ yielding iC3b (Martin et al., 2016). Clearly, additional studies are needed to form a complete understanding of the significance of intracellular complement activation and its potential relationship with host defense.

Tam and colleagues demonstrated that the presence of C3 peptides in the cytosol may also serve as molecular patterns that initiate danger signaling (Tam et al., 2014). A variety of C3-opsonized microbes, including both RNA and DNA non-enveloped viruses and the $\triangle$ sifA mutant of Salmonella, activated a NF- $\mathrm{B}$-driven luciferase reporter when present in the cytosol. The reporter was not activated when cytosolic entry was prevented or when pathogens were not opsonized with C3. Latex beads opsonized with a mixture of purified C3, FB and FD also activated NF- $\kappa$ B when transfected into HEK293T cells, suggesting that recognition of microbial patterns was not essential for this response. Signaling initiated by cytosolic C3 was independent of the signaling intermediates MyD88, TRIF, RIG-I, MDA5, Syk, and STING, but appeared to involve the mitochondrial antiviral signaling (MAVS) protein and TNF receptor-associated factor (TRAF). Cytosolic C3 sensing was observed in a variety of non-immune mammalian cell lines indicating that the proposed C3-detection pathway may be active in a number of cell types. However, it remains unknown whether macrophages sense cytosolic C3 in this manner. It should also be noted that these findings have not, as yet, been confirmed by other investigators and that a putative cytosolic C3 sensor has not yet been identified. This laboratory has identified tripartite motif-containing 21 (TRIM21) as a cytosolic sensor for IgG and IgM that also leads to the activation of $\mathrm{NF}-\kappa \mathrm{B}$ and interferon regulatory factors (James et al., 2007; Mallery et al., 2010; McEwan et al., 2013). The notion that C3 peptides mediate similar intracellular surveillance is quite provocative and certainly worthy of further study.

\section{COMPLEMENT ACTIVATION BY F. TULARENSIS}

In the conventional sense, $F$. tularensis is relatively serum resistant, meaning that it can survive in human serum (HS) without succumbing to the lytic effects of complement (Lofgren et al., 1983; Sorokin et al., 1996). Serum resistance appears to be conferred by the lipopolysaccharide (LPS) and cell wall structure of $F$. tularensis, as evidence by the increased activation of complement (especially via the classical pathway) and susceptibility to serum-mediated lysis of LPS and capsule mutants (Sandstrom et al., 1988; Sorokin et al., 1996; Clay et al., 2008; Lindemann et al., 2011). It is possible that mutations in other F. tularensis genes similarly alter the density of iC3b deposition following serum opsonization. Additionally, growth of $F$. tularensis in different culture media, which can alter the expression of high molecular weight surface carbohydrates, can affect the extent of C3 deposition on the bacterial surface (Zarrella et al., 2011). During opsonization of F. tularensis in HS, FH can bind to serum-opsonized F. tularensis (Ben Nasr and Klimpel, 2008), promoting the conversion of C3b to iC3b. This prevents the assembly of the membrane attack complex on the bacterial surface (Ben Nasr and Klimpel, 2008; Clay et al., 2008). F. tularensis may also express a surface CD59-like peptide (Madar et al., 2015), which may further hinder formation of the membrane attack complex by binding $\mathrm{C} 8$ or $\mathrm{C} 9$.

Several reports indicate that both the classical and alternative pathways are activated by F. tularensis (Ben Nasr and Klimpel, 2008; Clay et al., 2008) and include the observation that C1q is required for $\mathrm{C} 3$ deposition on the bacterium under certain conditions (Fulop et al., 1993; Clay et al., 2008; Schwartz et al., 2012). Natural IgM antibodies appear to play a role in complement activation by $F$. tularensis via the classical complement pathway (Sandstrom et al., 1988; Schwartz et al., 2012). Schwartz et al. showed that human serum (HS) from donors without a history of tularemia contained IgM antibodies that reacted with $F$. tularensis and mediated C3 deposition during the first $30 \mathrm{~min}$ of opsonization. Ben Nasr and Klimpel (2008) reported that, although the classical pathway was activated, they were unable to detect binding of serum IgM to F. tularensis. Balagopal et al. (2006) used immunofluorescence and ELISA to detect antibodies bound to F. novicida following opsonization of 
the bacteria with HS. The differences between these reports may reflect the bacterial strains that were studied or the use of different techniques to detect antibody binding. Regardless, there appears to exist sufficient evidence to conclude that the classical pathway can mediate C3 opsonization of F. tularensis.

The classical pathway may be particularly important when serum opsonization occurs for periods of $<30 \mathrm{~min}$. Longer periods of incubation with serum may allow significant alternative pathway amplification and C3b deposition (Ben Nasr and Klimpel, 2008). We have found that uptake of F. tularensis SCHU S4 by human macrophages over $3 \mathrm{~h}$ is significantly reduced in C3-depleted HS compared to HS (Brock and Parmely, 2017). However, there is no difference in the level of SCHU S4 uptake during a 3-h incubation in C1q-depleted HS compared to HS (Brock and Parmely, unpublished). Likewise, Ben Nasr and Klimpel (2008) reported that EGTA chelation of $\mathrm{Ca}^{2+}$ ions necessary for classical pathway activation in HS delayed the deposition of $\mathrm{iC} 3 \mathrm{~b}$ on $F$. tularensis if opsonization was limited to $30 \mathrm{~min}$. After $45 \mathrm{~min}$ of opsonization, there was no difference between the levels of $\mathrm{iC} 3 \mathrm{~b}$ deposition that occurred in HS and EGTA-treated HS (Ben Nasr and Klimpel, 2008). Conversely, treatment of HS with EDTA, which chelates both $\mathrm{Ca}^{2+}$ and $\mathrm{Mg}^{2+}$ and blocks both classical and alternative pathways, prevented any detectable iC3b deposition on SCHU S4 for at least $1 \mathrm{~h}$ (Ben Nasr and Klimpel, 2008). Thus, it appears that both the classical and alternative pathways can mediate complement activation during serum opsonization of $F$. tularensis.

\section{COMPLEMENT-MEDIATED UPTAKE OF F. TULARENSIS}

For a more comprehensive summary on the role of various cell surface receptors in the uptake of F. tularensis, the reader is referred to an excellent review by Moreau and Mann (Moreau and Mann, 2013). Our focus here will be limited to the receptors involved in complement-dependent uptake of F. tularensis.

Complement component C3 was first shown to be important for optimal uptake of $F$. tularensis by human monocyte-derived macrophages (MDMs) by replenishing C3-depleted serum with C3 protein (Clemens et al., 2005). This resulted in a C3 concentration-dependent uptake of bacteria. The importance of C3 in the uptake of F. tularensis has since been confirmed by several other groups (Dai et al., 2013; Brock and Parmely, 2017). Antibody blocking of CR3 with anti-CD11b and anti-CD18 reduced the uptake of HS-opsonized $F$. tularensis by human MDM (Clemens et al., 2005). Additional studies on blocking of complement receptors with antibodies have demonstrated that CR3 and CR4 are the predominant receptors involved in the uptake of HS-opsonized F. tularensis by human macrophages (Schulert and Allen, 2006; Schwartz et al., 2012). However, blocking antibodies often show relatively modest effects in this context. The use of siRNA to inhibit expression of CR3 in human MDM has also demonstrated that CR3 is an important receptor for the uptake of serum-opsonized SCHU S4 (Dai et al., 2013) and is consistent with the observation that C3 deposited on F. tularensis during HS opsonization is rapidly converted to iC3b.
Inactivated $\mathrm{C} 3 \mathrm{~b}$, not $\mathrm{C} 3 \mathrm{~b}$, is the primary ligand for $\mathrm{CR} 3$ and CR4. CR1 does not appear to play a significant role in the uptake of serum-opsonized F. tularensis by human MDM, based on antibody blocking of CR1 (Schwartz et al., 2012).

Another experimental approach for determining important receptor-ligand interactions in C3-mediated uptake of F. tularensis has involved heat inactivation of $\mathrm{HS}$ to block complement activation or selective depletion of individual complement components, both of which yield greater effects on uptake than receptor blocking with antibodies. Perhaps blocking antibodies lack the affinity required to compete with high affinity natural ligands. Alternatively, incomplete blocking by antibodies to CRs may indicate that other receptors also mediate uptake of serum-opsonized F. tularensis. For example, Class A scavenger receptors have been shown to bind iC3b (Goh et al., 2010) and have been implicated in the uptake of serum-opsonized F. tularensis (Pierini, 2006; Geier and Celli, 2011). Balagopal et al. (2006) suggested that Fc $\gamma$-receptors on human MDM could also contribute to uptake of serum-opsonized $F$. novicida. A role for CRIg in the uptake of serum-opsonized F. tularensis has not been investigated. CRIg is a complement receptor expressed on tissue macrophages which binds the beta chain of $\mathrm{C} 3$, allowing the receptor to phagocytize both $\mathrm{C} 3 \mathrm{~b}$ - and $\mathrm{iC} 3 \mathrm{~b}$-opsonized particles. The receptor has been shown to be important for the clearance of pathogens (Helmy et al., 2006; van Lookeren Campagne et al., 2007). Thus, although our knowledge of all the receptors that mediate the uptake of serum-opsonized F. tularensis may be incomplete, iC3b and CR3 likely play dominate roles in Francisella opsonophagocytosis by macrophages.

Complement C3-mediated uptake of F. tularensis is not restricted to macrophages. Ben Nasr et al. showed that C3 is also required for increased uptake of $F$. tularensis by human monocyte-derived dendritic cells. Opsonization with C3-depeleted HS resulted in levels of uptake similar to those observed with un-opsonized bacteria (Ben Nasr et al., 2006; Ben Nasr and Klimpel, 2008). Blocking with antibodies to CD11b and CD11c identified CR3 and CR4 as important for enhanced uptake by dendritic cells (Ben Nasr et al., 2006). By contrast, blocking Fc receptors had little effect (Ben Nasr et al., 2006). In similar receptor blocking studies, Schwartz et al. (2012) found that CR1 (CD35) and CR3 (CD11b) mediated uptake of HS-opsonized F. tularensis by human neutrophils (Schwartz et al., 2012). These studies illustrate that different cells utilize a range of complement receptors to phagocytize serum-opsonized F. tularensis.

\section{EFFECTS OF COMPLEMENT ON F. TULARENSIS INFECTION OF MACROPHAGES}

Complement C3-opsonization appears to have more effects than simply increasing the number of $F$. tularensis bacteria that are phagocytized. Clemens et al. showed that both nonopsonized and HS-opsonized F. tularensis LVS were taken up by a unique process, referred to as "looping phagocytosis," which involved spacious, asymmetric pseudopod loops (Clemens et al., 2005, 2012). An O-antigen-deficient LVS mutant was also 
phagocytized via looping in the absence of serum. However, the morphology of uptake of this serum-sensitive $\mathrm{O}$-antigen mutant was altered in the presence of C7-deficient serum, which allowed for opsonization but prevented complement-mediated bacteriolysis (Clemens et al., 2012). C7-deficient serum promoted uptake of the mutant in very tight loops. As serum-sensitive Oantigen mutants support increased C3-deposition (Clay et al., 2008), the authors suggested that an increased interaction between bacterial surface bound C3 peptides and macrophage complement receptors likely led to closer physical interactions at the host-microbe interface (Clemens et al., 2012). An important unanswered question is whether this morphological change leads to different signaling in the host cell.

Geier and Celli demonstrated that CR3 was important in the uptake by mouse bone marrow-derived macrophages (BMM) of HS-opsonized SCHU S4 (Geier and Celli, 2011). Uptake of HSopsonized SCHU S4 delayed the maturation of the phagosome as measured by the expression of LAMP-1. Baudino et al. have also reported a delay in phagosome maturation associated with the uptake of C3-opsonized apoptotic cells (Baudino et al., 2014). Uptake via CR3 decreased the proportion of SCHU S4 bacteria that escaped phagosomes measured at $30 \mathrm{~min}$ PI (Geier and Celli, 2011). However, differences between phagosome escape of HS-opsonized bacteria by wild-type BMM and CD11b-deficient BMM were lost by $45 \mathrm{~min}$ PI, suggesting the effect was only temporary.

Geier and Celli also concluded that HS-opsonization restricted the replication of the pathogen measured at $12 \mathrm{~h}$ PI. Our own studies with human macrophages indicate that intracellular replication rates of SCHU S4 in human macrophages are not affected by C3-opsonization (Brock and Parmely, 2017). SCHU S4 bacteria taken up in HS did not evidence any impaired ability to replicate to high densities within human primary macrophages. It should be noted that the time required for maximum $F$. tularensis escape from phagosomes appears to be greater in human THP-1 cells and primary macrophages (Clemens et al., 2004) than is observed in murine BMM (Geier and Celli, 2011), and this may explain some of the differences between these studies. Similarly, the percentage of HS-opsonized bacteria that ultimately do escape the phagosome appears to be higher in human macrophages (typically 80\%) (Clemens et al., 2004; Brock and Parmely, 2017) than mouse macrophages (typically $~ 55 \%$ ) (Geier and Celli, 2011). Another distinction between these mouse and human studies is the use of human serum as the source of opsonins in both cases. This approach assumes that human C3 interacts with human and mouse complement receptors in a similar manner and that signaling from both species of receptors is also the same.

Dai et al. reported that the binding of C3-opsonized SCHU S4 to CR3 altered the human macrophage response to infection by suppressing inflammatory cytokine production induced by TLR2 (Dai et al., 2013). By comparing infection of MDM with SCHU S4 in C3-depleted and C3-replenished human serum, the investigators found that the presence of C3-opsonization decreased the phosphorylation of MAP kinases ERK and p38 and decreased levels of secreted TNF, IL-6 and IL-1 $\beta$.
Serum opsonization of SCHU S4 also resulted in less NF$\kappa \mathrm{B}$ phosphorylation and nuclear translocation. Using siRNA to inhibit expression of CD11b or TLR2, they demonstrated that TLR2 activated pro-inflammatory responses to F. tularensis and that CR3 inhibited TLR2 signaling. CR3 inhibition of TLR2 signaling was mediated through phosphorylation of Lyn kinase.

These studies indicate that the binding and uptake of C3opsonized F. tularensis has a number of effects beyond the promotion of phagocytosis. C3 mediates a different morphology of uptake, significant changes in early host cell signaling pathways, subtle changes in intracellular trafficking and even altered survival of infected macrophages (Brock and Parmely 2017), which will now be discussed in more detail.

\section{C3 CONTROLS MACROPHAGE SURVIVAL DURING INFECTION WITH TYPE A F. TULARENSIS}

While studying infections of human MDM with $F$. tularensis SCHU S4, we observed that large numbers of macrophages in infected cultures died by $24 \mathrm{~h}$ PI and that cell death was C3dependent (Brock and Parmely, 2017). Death was rare among macrophages that had been infected in the presence of heatinactivated or C3-depleted serum. Single cell analysis by confocal microscopy revealed that a high cytosolic bacterial burden was not required for C3-dependent macrophage death. Many cells that bore only a few bacteria died as long as uptake had been facilitated by the presence of fresh HS. Conversely, half of macrophages that contained more than 100 bacteria did not die by $24 \mathrm{~h}$ PI when bacteria were taken up in a C3-dependent fashion. Some MDM in cultures that had been infected with C3-opsonized SCHU S4 lacked any detectable bacteria, and very few of these bystander cells died. Acknowledging that differences in the extent of bacterial uptake existed between the two opsonization conditions, we equalized initial uptake of the pathogen in HS and C3-depleted HS by adjusting the multiplicities of infection (MOI). When initial uptake levels were equivalent, similar bacterial growth occurred under the two conditions, but macrophage death was only seen in the presence of C3. We concluded that high bacterial burden was neither necessary nor sufficient for cell death induction, which was confirmed by infections with the replication-deficient SCHU S4 $\triangle$ purMCD mutant. Despite its limited intracellular replication, the HS-opsonized $\triangle p u r M C D$ mutant strain escaped the phagosome and induced cell death at levels equivalent to those seen in wild type SCHU S4-infected cultures. C3-dependent uptake alone did not explain the induction of macrophage death, as shown by the failure of the phagosome escape-deficient mutant SCHU S4 $\Delta f e v R$ to induce death of MDM, despite C3 opsonization. These findings suggest that two conditions need to be met for macrophage death. First, the cells must contain the pathogen. Second, uptake must occur in a C3-dependent fashion. While we do not yet know all of the details of this process, C3 appears to be emerging as an important factor in the induction of macrophage death that is so commonly seen in tularemia (Parmely et al., 2009). 
The experiments of Tam et al. (2014) reviewed above provide a potential context for understanding how complement promotes macrophage death following infection with type A F. tularensis. This group demonstrated that cytosolic C3 peptides, likely in the form of $\mathrm{C} 3 \mathrm{~b}$, can activate $\mathrm{NF}-\kappa \mathrm{B}$ in a number of cell types. If this cellular response was initiated by the sensing of a cytosolic C3 peptide, as postulated by the authors, it would provide a reasonable hypothesis for explaining what we have observed during F. tularensis infections of human macrophages. Accordingly, we suggest that $\mathrm{C} 3$ peptides, including $\mathrm{iC} 3 \mathrm{~b}$, are recognized in the cytosol of macrophages as molecular patterns and that the response to them is directed toward cell death, rather than NF- $\kappa$ B activation, by type A F. tularensis (Figure 3). This pathogen has a well-established anti-inflammatory phenotype, which includes its ability to inhibit NF- $\kappa$ B activation (Telepnev et al., 2003, 2005; Bosio et al., 2007; Butchar et al., 2008; Chase et al., 2009; Dotson et al., 2013; Bauler et al., 2014; Ghonime et al., 2015; Putzova et al., 2017). C3-dependent uptake of F. tularensis by CR3 further inhibits NF- $\kappa \mathrm{B}$ activation and pro-inflammatory gene expression in human macrophages (Dai et al., 2013).

Our prediction that C3 peptides induce macrophage death after SCHU S4 entry into the cytosol rests, in part, on studies with the phagosome escape SCHU S4 $\Delta f e v R$ mutant. Strains deficient in FevR have been used by others to determine the importance of phagosome escape in various aspects of infection of and immunity to F. tularensis (Wehrly et al., 2009; Long et al., 2013). However, it should be noted that FevR is a global transcriptional regulator and controls the expression of a number of F. tularensis genes.

Our hypothesis would predict that C3 peptides enter the cytosol with $F$. tularensis. Human serum-opsonized F. tularensis bears covalently attached $\mathrm{C} 3 \mathrm{~b}$ and $\mathrm{iC} 3 \mathrm{~b}$ when it is taken up by cells, although the fate of these peptides during their extended stay in the phagosome is unknown. Phagosome escape by SCHU $\mathrm{S} 4$ in human macrophages is not complete until $8 \mathrm{~h}$ PI. In this context, it remains unclear whether the pathogen contributes more to macrophage death induction than simply transporting the relevant $\mathrm{C} 3$ peptides into the cytosol, but we expect that it does. Tam et al. (2014) were able to elicit a NF- $\kappa$ B response in HEK293T cells by simply transfecting the cells with latex beads opsonized with the purified complement components $\mathrm{C} 3, \mathrm{FB}$ and FD. This would suggest that the NF- $\kappa$ B response does not require a microbial component and that cytosolic $\mathrm{C} 3$ peptides may be sufficient for this response. Tam et al. (2014) did not report on the viability of the host cell following the transfection of C3 peptides into the cytosol. Thus, it remains to be determined if cytosolic C3 or cytosolic C3 fragments alone are sufficient to trigger macrophage death. Because both $F$. tularensis itself and CR3 engagement are capable of inhibiting NF- $\kappa \mathrm{B}$ activation (Telepnev et al., 2003; Dai et al., 2013; Putzova et al., 2017), we propose that the response to cytosolic C3 in F. tularensis-infected macrophages is diverted to a cell death pathway (Figure 3). This would explain the requirement for $\mathrm{C} 3$-opsonization and align our findings with the $\mathrm{C} 3$ sensing model proposed by Tam and colleagues.

Testing the hypothesis that cell death is initiated by the combined effects of C3 peptides and F. tularensis may be best

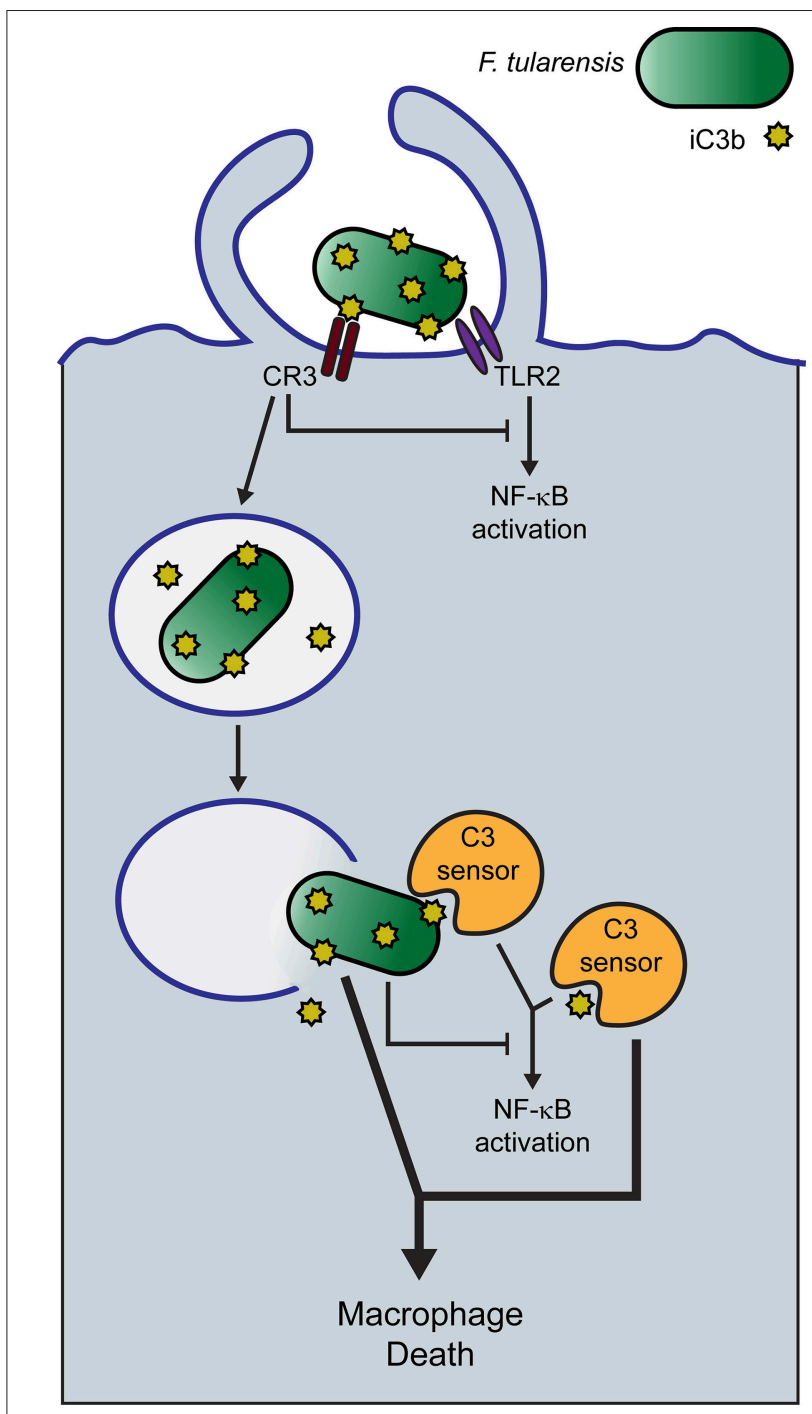

FIGURE 3 | Hypothetical model of serum-opsonized F. tularensis-induced human macrophage death. Human serum-opsonized $F$. tularensis delivers C3 peptides into the cytosol of macrophages upon phagosome escape of the pathogen. Cytosolic F. tularensis and sensing of cytosolic C3 peptides trigger macrophage death.

undertaken by the direct delivery of these components into the cytosol of macrophages by methods such as those described by Meyer et al. (2015) or Wu et al. (2015). These experimental approaches would allow one to isolate the effects of the cytosolic microenvironment from those stages of infection preceding phagosome escape and evaluate more precisely the nature of $\mathrm{C} 3$, the bacterial components and the host cell recognition process that combines to trigger macrophage death.

What role does CR3, which mediates the uptake of C3opsonized SCHU S4 by human macrophages, play in signaling cell death? Two observations may be relevant. Dai et al. (2013) showed that human MDM infected with C3-opsonized SCHU S4 produced decreased amounts of IL-1 $\beta$, a finding we confirmed in our own studies (Brock and Parmely, 2017). Release of IL$1 \beta$ requires inflammasome-mediated caspase- 1 activation, which 
is not a characteristic of type A F. tularensis (Dotson et al., 2013; Ghonime et al., 2015). Thus, it is unlikely that CR3 binding of C3-opsonized SCHU S4 induces caspase-1-mediated pyroptosis in human macrophages as has been reported for mouse macrophages infected with F. novicida (Mariathasan et al., 2005; Henry et al., 2007; Peng et al., 2011). A second finding is also relevant. When we first infected human MDM at high MOI with SCHU S4 opsonized with C3-depleted serum and then infected these cells with C3-opsonized SCHU S4 $\Delta \mathrm{fevR}$ mutant bacteria, the infected macrophages remained viable. Secondary infection with C3-opsonized wild type SCHU S4 resulted in macrophage death. Likewise, infection with C3-opsonized SCHU S4 $\Delta f e v R$ alone also did not induce macrophage death, whereas C3-opsonized wild type SCHU S4 alone did. This illustrates that CR3 engagement is not a sufficient death signal, even in macrophages infected with high numbers of intracellular bacteria lacking C3 peptides. A reasonable explanation for these findings is that macrophage death requires both cytosolic F. tularensis and cytosolic C3 peptides. While it cannot be ruled out that CR3 signaling (Dai et al., 2013) contributes to macrophage death, there is also no reason to assume that CR3-mediated uptake of C3-opsonized F. tularensis is required for cell death induction. CR3 may simply be the most efficient receptor for assuring a high frequency of infected cells.

Although a putative C3 sensor remains to be characterized, two likely ligands- $\mathrm{C} 3 \mathrm{~b}$ and $\mathrm{iC} 3 \mathrm{~b}$ - are predicted by available information. First, Tam and his colleagues implied that the ligand was $\mathrm{C} 3 \mathrm{~b}$ by the few components- $\mathrm{C} 3, \mathrm{FB}$ and $\mathrm{FD}$ - that were required for opsonizing latex beads capable of activating NF$\kappa \mathrm{B}$ following their transfection into cells (Tam et al., 2014). Second, when F. tularensis SCHU S4 is opsonized with HS, $\mathrm{iC} 3 \mathrm{~b}$ is the predominant peptide covalently attached to the organism (Ben Nasr and Klimpel, 2008; Clay et al., 2008; Brock and Parmely, 2017). This is consistent with the high levels of uptake of C3-opsonized F. tularensis by human macrophages being mediated by CR3 (Clemens et al., 2005; Schwartz et al., 2012; Dai et al., 2013), which shows high affinity for iC3b (Table 1).

Previous studies of mice infected with type A F. tularensis revealed a caspase-3-dependent pathway of macrophage death (Parmely et al., 2009; Wickstrum et al., 2009). However, to date, we have been unable to determine the cell death pathway activated by $\mathrm{C} 3$-opsonized SCHU S4 in human MDM. The extended period of time between infection with $F$. tularensis and macrophage death has suggested to some that a causal relationship exists between achieving a sufficient intracellular bacterial burden and cell death induction. However, recently published findings (Brock and Parmely, 2017) described above are inconsistent with this interpretation. If the kinetics of cell death reflects an apoptotic process, which can take up to $24 \mathrm{~h}$ (Saraste and Pulkki, 2000), then the delay in the appearance of overt signs of cell death (e.g., LDH release) may reflect the variability in apoptosis induction among individual cells, the complex nature of signaling pathways or the lengthy degradative processes necessary for loss of membrane integrity leading to $\mathrm{LDH}$ release.

Francisella tularensis is likely to encounter the complement system quite early in infection, given the range of cells that produce complement components and the high concentrations of these components in body fluids, especially plasma, alveolar fluids and inflammatory exudates (Schenkein and Genco, 1978; Watford et al., 2000; Holers, 2014; Lubbers et al., 2017). Complement activation by extracellular microbial pathogens has traditionally been viewed as benefiting the host by mediating clearance, leukocyte chemotaxis and altered vascular permeability at sites of infection. However, this view needs to be balanced by recent reports that $F$. tularensis utilizes complement to its own advantage by avoiding many complement effector mechanisms, regulating innate immune cell activation and controlling host cell viability to promote its own survival, intracellular replication and dissemination. Caution is urged in considering therapeutic approaches to infection that might affect complement activation by $F$. tularensis. Clearly, the pathogen has a complicated and largely mysterious relationship with the complement system that deserves additional study to appreciate fully its role in tularemia pathogenesis.

\section{ETHICS STATEMENT}

This study was carried out in accordance with the recommendations of the human subjects research guidelines of the University of Kansas Medical Center Institutional Review Board with written informed consent from all subjects. All subjects gave written informed consent in accordance with the Declaration of Helsinki. The protocol was approved by the University of Kansas Medical Center Institutional Review Board.

\section{AUTHOR CONTRIBUTIONS}

SB and MP both contributed to the design, conception, and writing of this manuscript.

\section{FUNDING}

The laboratory of MP was funded by NIAID grant AI093921 from the National Institutes of Health and a Lied Basic Science Grant from the University of Kansas Medical Center Research Institute. SB was supported by a Biomedical Research Training Program grant from the University of Kansas Medical Center.

\section{ACKNOWLEDGMENTS}

The authors would like to thank Catharine Bosio, Jean Celli, and Lee-Ann Allen for providing Francisella strains which aided in this research. 


\section{REFERENCES}

Arbore, G., Kemper, C., and Kolev, M. (2017). Intracellular complementthe complosome-in immune cell regulation. Mol. Immunol. 89, 2-9. doi: 10.1016/j.molimm.2017.05.012

Balagopal, A., MacFarlane, A. S., Mohapatra, N., Soni, S., Gunn, J. S., and Schlesinger, L. S. (2006). Characterization of the receptor-ligand pathways important for entry and survival of Francisella tularensis in human macrophages. Infect. Immun. 74, 5114-5125. doi: 10.1128/IAI.00795-06

Barel, M., Hovanessian, A. G., Meibom, K., Briand, J. P., Dupuis, M., and Charbit, A. (2008). A novel receptor-ligand pathway for entry of Francisella tularensis in monocyte-like THP-1 cells: interaction between surface nucleolin and bacterial elongation factor Tu. BMC Microbiol. 8:145. doi: 10.1186/1471-2180-8-145

Baudino, L., Sardini, A., Ruseva, M. M., Fossati-Jimack, L., Cook, H. T., Scott, D., et al. (2014). C3 opsonization regulates endocytic handling of apoptotic cells resulting in enhanced T-cell responses to cargo-derived antigens. Proc. Natl. Acad. Sci. U.S.A. 111, 1503-1508. doi: 10.1073/pnas.1316877111

Bauler, T. J., Chase, J. C., Wehrly, T. D., and Bosio, C. M. (2014). Virulent Francisella tularensis destabilize host mRNA to rapidly suppress inflammation. J. Innate Immun. 6, 793-805. doi: 10.1159/000363243

Ben Nasr, A., Haithcoat, J., Masterson, J. E., Gunn, J. S., Eaves-Pyles, T., and Klimpel, G. R. (2006). Critical role for serum opsonins and complement receptors CR3 (CD11b/CD18) and CR4 (CD11c/CD18) in phagocytosis of Francisella tularensis by human dendritic cells (DC): uptake of Francisella leads to activation of immature DC and intracellular survival of the bacteria. J. Leukoc. Biol. 80, 774-786. doi: 10.1189/jlb.1205755

Ben Nasr, A., and Klimpel, G. R. (2008). Subversion of complement activation at the bacterial surface promotes serum resistance and opsonophagocytosis of Francisella tularensis. J. Leukoc. Biol. 84, 77-85. doi: 10.1189/jlb.0807526

Bosio, C. M., Bielefeldt-Ohmann, H., and Belisle, J. T. (2007). Active suppression of the pulmonary immune response by Francisella tularensis Schu4. J. Immunol. 178, 4538-4547. doi: 10.4049/jimmunol.178.7.4538

Brock, S. R., and Parmely, M. J. (2017). Complement C3 as a prompt for human macrophage death during infection with Francisella tularensis strain SCHU S4. Infect. Immun. 85:e0424-17. doi: 10.1128/IAI.00424-17

Butchar, J. P., Cremer, T. J., Clay, C. D., Gavrilin, M. A., Wewers, M. D., Marsh, C. B., et al. (2008). Microarray analysis of human monocytes infected with Francisella tularensis identifies new targets of host response subversion. PLoS ONE 3:e2924. doi: 10.1371/journal.pone.0002924

Chase, J. C., Celli, J., and Bosio, C. M. (2009). Direct and indirect impairment of human dendritic cell function by virulent Francisella tularensis Schu S4. Infect. Immun. 77, 180-195. doi: 10.1128/IAI.00879-08

Chen, Z. A., Pellarin, R., Fischer, L., Sali, A., Nilges, M., Barlow, P. N., et al. (2016). Structure of complement $\mathrm{C} 3(\mathrm{H} 2 \mathrm{O})$ revealed by quantitative crosslinking/mass spectrometry and modeling. Mol. Cell. Proteomics 15, 2730-2743. doi: 10.1074/mcp.M115.056473

Chong, A., Wehrly, T. D., Nair, V., Fischer, E. R., Barker, J. R., Klose, K. E., et al. (2008). The early phagosomal stage of Francisella tularensis determines optimal phagosomal escape and Francisella pathogenicity island protein expression. Infect. Immun. 76, 5488-5499. doi: 10.1128/IAI.00682-08

Clay, C. D., Soni, S., Gunn, J. S., and Schlesinger, L. S. (2008). Evasion of complement-mediated lysis and complement C3 deposition are regulated by Francisella tularensis lipopolysaccharide $\mathrm{O}$ antigen. J. Immunol. 181, 5568-5578. doi: 10.4049/jimmunol.181.8.5568

Clemens, D. L., Lee, B. Y., and Horwitz, M. A. (2004). Virulent and avirulent strains of Francisella tularensis prevent acidification and maturation of their phagosomes and escape into the cytoplasm in human macrophages. Infect. Immun. 72, 3204-3217. doi: 10.1128/IAI.72.6.3204-3217.2004

Clemens, D. L., Lee, B. Y., and Horwitz, M. A. (2005). Francisella tularensis enters macrophages via a novel process involving pseudopod loops. Infect. Immun. 73, 5892-5902. doi: 10.1128/IAI.73.9.5892-5902.2005

Clemens, D. L., Lee, B. Y., and Horwitz, M. A. (2012). O-antigen-deficient Francisella tularensis Live Vaccine Strain mutants are ingested via an aberrant form of looping phagocytosis and show altered kinetics of intracellular trafficking in human macrophages. Infect. Immun. 80, 952-967. doi: 10.1128/IAI.05221-11

Dai, S., Rajaram, M. V., Curry, H. M., Leander, R., and Schlesinger, L. S. (2013). Fine tuning inflammation at the front door: macrophage complement receptor 3-mediates phagocytosis and immune suppression for Francisella tularensis. PLoS Pathog. 9:e1003114. doi: 10.1371/journal.ppat.1003114

Dennis, D. T., Inglesby, T. V., Henderson, D. A., Bartlett, J. G., Ascher, M. S., Eitzen, E., et al. (2001). Tularemia as a biological weapon: medical and public health management. JAMA 285, 2763-2773. doi: 10.1001/jama.285.21.2763

Dotson, R. J., Rabadi, S. M., Westcott, E. L., Bradley, S., Catlett, S. V., Banik, S., et al. (2013). Repression of inflammasome by Francisella tularensis during early stages of infection. J. Biol. Chem. 288, 23844-23857. doi: 10.1074/jbc.M113.490086

Dunkelberger, J. R., and Song, W. C. (2010). Complement and its role in innate and adaptive immune responses. Cell Res. 20, 34-50. doi: 10.1038/cr.2009.139

Elvington, M., Liszewski, M. K., and Atkinson, J. P. (2016). Evolution of the complement system: from defense of the single cell to guardian of the intravascular space. Immunol. Rev. 274, 9-15. doi: 10.1111/imr.12474

Elvington, M., Liszewski, M. K., Bertram, P., Kulkarni, H. S., and Atkinson, J. P. (2017). A C3(H20) recycling pathway is a component of the intracellular complement system. J. Clin. Invest. 127, 970-981. doi: 10.1172/JCI89412

Feldman, K. A., Enscore, R. E., Lathrop, S. L., Matyas, B. T., McGuill, M., Schriefer, M. E., et al. (2001). An outbreak of primary pneumonic tularemia on Martha's Vineyard. N. Engl. J. Med. 345, 1601-1606. doi: 10.1056/NEJMoa011374

Fulop, M., Webber, T., and Manchee, R. (1993). Activation of the complement system by Francisella tularensis lipopolysaccharide. New Microbiol. 16, 141-147.

Geier, H., and Celli, J. (2011). Phagocytic receptors dictate phagosomal escape and intracellular proliferation of Francisella tularensis. Infect. Immun. 79, 2204-2214. doi: 10.1128/IAI.01382-10

Ghonime, M. G., Mitra, S., Eldomany, R. A., Wewers, M. D., and Gavrilin, M. A. (2015). Inflammasome priming is similar for francisella species that differentially induce inflammasome activation. PLOS ONE 10:e0127278. doi: 10.1371/journal.pone.0127278

Goh, J. W., Tan, Y. S., Dodds, A. W., Reid, K. B., and Lu, J. (2010). The class A macrophage scavenger receptor type I (SR-AI) recognizes complement iC3b and mediates NF-kappaB activation. Protein Cell 1, 174-187. doi: 10.1007/s13238-010-0020-3

Golovliov, I., Baranov, V., Krocova, Z., Kovarova, H., and Sjostedt, A. (2003). An attenuated strain of the facultative intracellular bacterium Francisella tularensis can escape the phagosome of monocytic cells. Infect. Immun. 71, 5940-5950. doi: 10.1128/IAI.71.10.5940-5950.2003

Hall, J. D., Woolard, M. D., Gunn, B. M., Craven, R. R., Taft-Benz, S., Frelinger, J. A., et al. (2008). Infected-host-cell repertoire and cellular response in the lung following inhalation of Francisella tularensis Schu S4, LVS, or U112. Infect. Immun. 76, 5843-5852. doi: 10.1128/IAI.01176-08

Helmy, K. Y., Katschke, K. J. Jr., Gorgani, N. N., Kljavin, N. M., Elliott, J. M., Diehl, L., et al. (2006). CRIg: a macrophage complement receptor required for phagocytosis of circulating pathogens. Cell 124, 915-927. doi: 10.1016/j.cell.2005.12.039

Henry, T., Brotcke, A., Weiss, D. S., Thompson, L. J., and Monack, D. M. (2007). Type I interferon signaling is required for activation of the inflammasome during Francisella infection. J. Exp. Med. 204, 987-994. doi: 10.1084 /jem.20062665

Holers, V. M. (2014). Complement and its receptors: new insights into human disease. Annu. Rev. Immunol. 32, 433-459. doi: 10.1146/annurev-immunol-032713-120154

James, L. C., Keeble, A. H., Khan, Z., Rhodes, D. A., and Trowsdale, J. (2007). Structural basis for PRYSPRY-mediated tripartite motif (TRIM) protein function. Proc. Natl. Acad. Sci. U.S.A. 104, 6200-6205. doi: 10.1073/pnas.0609174104

Kingry, L. C., and Petersen, J. M. (2014). Comparative review of Francisella tularensis and Francisella novicida. Front. Cell. Infect. Microbiol. 4:35. doi: 10.3389/fcimb.2014.00035

Kolev, M., Dimeloe, S., Le Friec, G., Navarini, A., Arbore, G., Povoleri, G. A., et al. (2015). Complement regulates nutrient influx and metabolic reprogramming during Th1 cell responses. Immunity 42, 1033-1047. doi: 10.1016/j.immuni.2015.05.024

Lai, X. H., Golovliov, I., and Sjöstedt, A. (2001). Francisella tularensis induces cytopathogenicity and apoptosis in murine macrophages via a mechanism that requires intracellular bacterial multiplication. Infect. Immun. 69, 4691-4694. doi: 10.1128/IAI.69.7.4691-4694.2001 
Leslie, R. G. Q. (2001). “Complement Receptors," in Encyclopedia of Life Sciences (John Wiley \& Sons, Ltd), 1-9. doi: 10.1038/npg.els.0000512

Lindemann, S. R., Peng, K., Long, M. E., Hunt, J. R., Apicella, M. A., Monack, D. M., et al. (2011). Francisella tularensis Schu S4 O-antigen and capsule biosynthesis gene mutants induce early cell death in human macrophages. Infect. Immun. 79, 581-594. doi: 10.1128/IAI.00863-10

Liszewski, M. K., Elvington, M., Kulkarni, H. S., and Atkinson, J. P. (2017). Complement's hidden arsenal: new insights and novel functions inside the cell. Mol. Immunol. 84, 2-9. doi: 10.1016/j.molimm.2017.01.004

Liszewski, M. K., Kolev, M., Le Friec, G., Leung, M., Bertram, P. G., Fara, A. F., et al. (2013). Intracellular complement activation sustains $\mathrm{T}$ cell homeostasis and mediates effector differentiation. Immunity 39, 1143-1157. doi: 10.1016/j.immuni.2013.10.018

Löfgren, S., Tärnvik, A., Bloom, G. D., and Sjöberg, W. (1983). Phagocytosis and killing of Francisella tularensis by human polymorphonuclear leukocytes. Infect. Immun. 39, 715-720.

Long, M. E., Lindemann, S. R., Rasmussen, J. A., Jones, B. D., and Allen, L. A. (2013). Disruption of Francisella tularensis Schu S4 iglI, iglJ, and pdpC genes results in attenuation for growth in human macrophages and in vivo virulence in mice and reveals a unique phenotype for pdpC. Infect. Immun. 81, 850-861. doi: 10.1128/IAI.00822-12

Lubbers, R., van Essen, M. F., van Kooten, C., and Trouw, L. A. (2017). Production of complement components by cells of the immune system. Clin. Exp. Immunol. 188, 183-194. doi: 10.1111/cei.12952

Madar, M., Bencurova, E., Mlynarcik, P., Almeida, A. M., Soares, R., Bhide, K., et al. (2015). Exploitation of complement regulatory proteins by Borrelia and Francisella. Mol. Biosyst. 11, 1684-1695. doi: 10.1039/C5MB00027K

Mallery, D. L., McEwan, W. A., Bidgood, S. R., Towers, G. J., Johnson, C. M., and James, L. C. (2010). Antibodies mediate intracellular immunity through tripartite motif-containing 21 (TRIM21). Proc. Natl. Acad. Sci. U.S.A. 107, 19985-19990. doi: 10.1073/pnas.1014074107

Mariathasan, S., Weiss, D. S., Dixit, V. M., and Monack, D. M. (2005). Innate immunity against Francisella tularensis is dependent on the ASC/caspase-1 axis. J. Exp. Med. 202, 1043-1049. doi: 10.1084/jem.20050977

Martin, M., Leffler, J., Smolag, K. I., Mytych, J., Björk, A., Chaves, L. D., et al. (2016). Factor $\mathrm{H}$ uptake regulates intracellular C3 activation during apoptosis and decreases the inflammatory potential of nucleosomes. Cell Death Differ. 23, 903-911. doi: 10.1038/cdd.2015.164

McCrumb, F. R. (1961). Aerosol infection of man with Pasteurella Tularensis. Bacteriol. Rev. 25, 262-267.

McEwan, W. A., Tam, J. C., Watkinson, R. E., Bidgood, S. R., Mallery, D. L., and James, L. C. (2013). Intracellular antibody-bound pathogens stimulate immune signaling via the Fc receptor TRIM21. Nat. Immunol. 14, 327-336. doi: 10.1038/ni.2548

Meyer, L., Broms, J. E., Liu, X., Rottenberg, M. E., and Sjostedt, A. (2015). Microinjection of Francisella tularensis and Listeria monocytogenes reveals the importance of bacterial and host factors for successful replication. Infect. Immun. 83, 3233-3242. doi: 10.1128/IAI.00416-15

Moreau, G. B., and Mann, B. J. (2013). Adherence and uptake of Francisella into host cells. Virulence 4, 826-832. doi: 10.4161/viru.25629

Nishida, N., Walz, T., and Springer, T. A. (2006). Structural transitions of complement component C3 and its activation products. Proc. Natl. Acad. Sci. U.S.A. 103, 19737-19742. doi: 10.1073/pnas.0609791104

Noris, M., and Remuzzi, G. (2013). Overview of complement activation and regulation. Semin. Nephrol. 33, 479-492. doi: 10.1016/j.semnephrol.2013.08.001

Parmely, M. J., Fischer, J. L., and Pinson, D. M. (2009). Programmed cell death and the pathogenesis of tissue injury induced by type A Francisella tularensis. FEMS Microbiol. Lett. 301, 1-11. doi: 10.1111/j.1574-6968.2009.01791.x

Peng, K., Broz, P., Jones, J., Joubert, L. M., and Monack, D. (2011). Elevated AIM2-mediated pyroptosis triggered by hypercytotoxic Francisella mutant strains is attributed to increased intracellular bacteriolysis. Cell. Microbiol. 13, 1586-1600. doi: 10.1111/j.1462-5822.2011.01643.x

Pierini, L. M. (2006). Uptake of serum-opsonized Francisella tularensis by macrophages can be mediated by class A scavenger receptors. Cell. Microbiol. 8, 1361-1370. doi: 10.1111/j.1462-5822.2006.00719.x

Plzakova, L., Krocova, Z., Kubelkova, K., and Macela, A. (2015). Entry of Francisella tularensis into murine B cells: the role of B cell receptors and complement receptors. PLoS ONE 10:e0132571. doi: 10.1371/journal.pone. 0132571

Putzova, D., Panda, S., Härtlova, A., Stulík, J., and Gekara, N. O. (2017). Subversion of innate immune responses by Francisella involves the disruption of TRAF3 and TRAF6 signalling complexes. Cell. Microbiol. 19:e12769. doi: $10.1111 / \mathrm{cmi} .12769$

Ricklin, D., Hajishengallis, G., Yang, K., and Lambris, J. D. (2010). Complement: a key system for immune surveillance and homeostasis. Nat. Immunol. 11, 785-797. doi: 10.1038/ni.1923

Roberts, L. M., Tuladhar, S., Steele, S. P., Riebe, K. J., Chen, C. J., Cumming, R. I., et al. (2014). Identification of early interactions between Francisella and the host. Infect. Immun. 82, 2504-2510. doi: 10.1128/IAI.01654-13

Sandström, G., Löfgren, S., and Tärnvik, A. (1988). A capsule-deficient mutant of Francisella tularensis LVS exhibits enhanced sensitivity to killing by serum but diminished sensitivity to killing by polymorphonuclear leukocytes. Infect. Immun. 56, 1194-1202.

Saraste, A., and Pulkki, K. (2000). Morphologic and biochemical hallmarks of apoptosis. Cardiovasc. Res. 45, 528-537. doi: 10.1016/S0008-6363(99)00384-3

Satyam, A., Kannan, L., Matsumoto, N., Geha, M., Lapchak, P. H., Bosse, R., et al. (2017). Intracellular activation of complement 3 is responsible for intestinal tissue damage during mesenteric ischemia. J. Immunol. 198, 788-797. doi: 10.4049/jimmunol.1502287

Schenkein, H. A., and Genco, R. J. (1978). Complement cleavage products in inflammatory exudates from patients with periodontal diseases. J. Immunol. 120, 1796-1796.

Schulert, G. S., and Allen, L. A. (2006). Differential infection of mononuclear phagocytes by Francisella tularensis: role of the macrophage mannose receptor. J. Leukoc. Biol. 80, 563-571. doi: 10.1189/jlb.0306219

Schwartz, J. T., Barker, J. H., Long, M. E., Kaufman, J., McCracken, J., and Allen, L. A. (2012). Natural IgM mediates complement-dependent uptake of Francisella tularensis by human neutrophils via complement receptors 1 and 3 in nonimmune serum. J. Immunol. 189, 3064-3077. doi: 10.4049/jimmunol.1200816

Sorokin, V. M., Pavlovich, N. V., and Prozorova, L. A. (1996). Francisella tularensis resistance to bactericidal action of normal human serum. FEMS Immunol. Med. Microbiol. 13, 249-252. doi: 10.1111/j.1574-695X.1996.tb00246.x

Steiner, D. J., Furuya, Y., Jordan, M. B., and Metzger, D. W. (2017). Protective role for macrophages in respiratory Francisella tularensis infection. Infect. Immun. 85:e00064-17. doi: 10.1128/IAI.00064-17

Stuart, B. M., and Pullen, R. L. (1945). Tularemic pneumonia: review of American literature and report of 15 additional cases. Am. J. Med. Sci. 210, 223-236. doi: 10.1097/00000441-194508000-00013

Tam, J. C., Bidgood, S. R., McEwan, W. A., and James, L. C. (2014). Intracellular sensing of complement C3 activates cell autonomous immunity. Science 345:1256070. doi: 10.1126/science. 1256070

Telepnev, M., Golovliov, I., Grundström, T., Tärnvik, A., and Sjöstedt, A. (2003). Francisella tularensis inhibits Toll-like receptor-mediated activation of intracellular signalling and secretion of TNF-alpha and IL-1 from murine macrophages. Cell. Microbiol. 5, 41-51. doi: 10.1046/j.1462-5822.2003.00251.x

Telepnev, M., Golovliov, I., and Sjostedt, A. (2005). Francisella tularensis LVS initially activates but subsequently down-regulates intracellular signaling and cytokine secretion in mouse monocytic and human peripheral blood mononuclear cells. Microb. Pathog. 38, 239-247. doi: 10.1016/j.micpath.2005.02.003

van Lookeren Campagne, M., Wiesmann, C., and Brown, E. J. (2007). Macrophage complement receptors and pathogen clearance. Cell. Microbiol. 9, 2095-2102. doi: 10.1111/j.1462-5822.2007.00981.x

Watford, W. T., Ghio, A. J., and Wright, J. R. (2000). Complement-mediated host defense in the lung. Am. J. Physiol. Lung Cell. Mol. Physiol. 279, L790-L798. doi: 10.1152/ajplung.2000.279.5.L790

Wehrly, T. D., Chong, A., Virtaneva, K., Sturdevant, D. E., Child, R., Edwards, J. A., et al. (2009). Intracellular biology and virulence determinants of Francisella tularensis revealed by transcriptional profiling inside macrophages. Cell. Microbiol. 11, 1128-1150. doi: 10.1111/j.1462-5822.2009.01316.x

Wickstrum, J. R., Bokhari, S. M., Fischer, J. L., Pinson, D. M., Yeh, H. W., Horvat, R. T., et al. (2009). Francisella tularensis induces extensive caspase-3 activation and apoptotic cell death in the tissues of infected mice. Infect. Immun. 77, 4827-4836. doi: 10.1128/IAI.00246-09 
Wu, Y. C., Wu, T. H., Clemens, D. L., Lee, B. Y., Wen, X., Horwitz, M. A., et al. (2015). Massively parallel delivery of large cargo into mammalian cells with light pulses. Nat. Methods 12, 439-444. doi: 10.1038/nmeth. 3357

Zarrella, T. M., Singh, A., Bitsaktsis, C., Rahman, T., Sahay, B., Feustel, P. J., et al. (2011). Host-adaptation of Francisella tularensis alters the bacterium's surfacecarbohydrates to hinder effectors of innate and adaptive immunity. PLOS ONE 6:e22335. doi: 10.1371/journal.pone.0022335

Zipfel, P. F., and Skerka, C. (2009). Complement regulators and inhibitory proteins. Nat. Rev. Immunol. 9, 729-740. doi: 10.1038/nri2620
Conflict of Interest Statement: The authors declare that the research was conducted in the absence of any commercial or financial relationships that could be construed as a potential conflict of interest.

Copyright $\odot 2017$ Brock and Parmely. This is an open-access article distributed under the terms of the Creative Commons Attribution License (CC BY). The use, distribution or reproduction in other forums is permitted, provided the original author(s) or licensor are credited and that the original publication in this journal is cited, in accordance with accepted academic practice. No use, distribution or reproduction is permitted which does not comply with these terms. 